\title{
COMPETITION BETWEEN SIX HEDGEROW TREE SPECIES AND MUNG BEAN (VIGNA RADIATA (L.) WILCZEK) IN THE MID-COUNTRY INTERMEDIATE ZONE
}

\author{
W.A.J.M. DE COSTA ${ }^{1 *}$ and A.G. CHANDRAPALA ${ }^{2}$ \\ Department of Crop Science, Faculty of Agriculture, University of Peradeniya, Peradeniya. \\ Natural Resource Management Centre, Department of Agriculture, Peradeniya.
}

(Received: 17 September 1999 ; accepted: 05 May 2000)

\begin{abstract}
Tree and annual crops in agroforestry systems compete for growth resources. The objective of this investigation was to partition the overall tree-crop competition into above- and below-ground components in contour hedgerow intercropping systems involving six tree species (Calliandlra culoth.yrsus, Desmodium. ransonii, Flemingia macrophyll.a, Gliricidia sepinum, Cassia spectabilis and. Tithonia diversifolica) and mung bean (Vigna rudiata) grown at Pallekelle in the mid-country intermediate zone $\left(\mathrm{IM}_{3}\right)$ of Sri Lanka. Lateral extension of tree roots to the area occupied by mung bean was prevented by cutting $1.5 \mathrm{~m}$ deep trenches at $25 \mathrm{~cm}$ from hedgerows. Below-ground (root) competition was estimated as the yield difference hetween trenching (TR) and non-trenching (NTR) treatments. Above-ground (shoot) competition was estimated as the yield difference between the yields of a sole crop control and TR. Mung bean yield reductions due to above-ground competition was greater than those due to below-ground competition in all hedgerow intercrops except that involving Gliricidlia in which the two components were approximately equal. Tutal competition (i.e. yield difference between control and NTR) and above-ground competition was highest by Cassia and lowest by Gliricidia. In terms of absolute yield reductions, below-ground competition was highest in Calliandra and lowest in Cassia. When computed as percentages of total competition, the highest and lowest below-ground competition were shown by Gliricicliu and Cussiu respectively. Variations between hedgerow species in biomass production capacity, the amount of nutrients added to the soil through prunings and the synchrony of their decomposition with periods of nutrient demand of the crop could be possible reasons for the observed inter-species variation of above- and below-ground enmpetition.
\end{abstract}

Keywords: Above-ground competition, below-ground competition, hedgerow intercropping, mung bean, Vigna radiata.

\section{INTRODUCTION}

Contour hedgerow intercropping is a simultaneous agroforestry system ${ }^{1}$ which has been recommended to sustain annual crop yields in sloping lands of the central highlands of Sri Lanka. It involves incorporation of fast-growing, coppiceable, multi-purpose tree species as hedgerows along contours and growing annual crops in the alleys inbetween. In a previous paper ${ }^{2}$, it was shown that there was significant competition between the tree hedge and the annual crop for essential

\footnotetext{
" Corresponding author'
} 
resources such as light, water and nutrients and that significant variation existed between different hedgerow tree species in the degree of competition exerted: The present study reports a continuation of the above work with the following objectives: (a) To partition the overall tree-crop competition into above-ground (shoot) and below-ground (root) competition; (b) To determine whether the degree of overall competition exerted by different hedgerow species followed the same pattern as in the previous experiment; and (c) To examine whether the as sociated mung bean (Vigna radiata. L. Wilczek) yields have been sustained in the second season.

\section{MATERIALS AND METHODS}

Experimental location: The experiment was conducted from June to October, 1998 at Kundasale ( $367 \mathrm{~m}$ above sea level) in Sri Lanka (7-8 $\mathrm{N} \& 80-81^{\prime \prime} \mathrm{E}$ ). The location had a distinctly bj-modal rainfall pattern of $1400 \mathrm{~mm} / \mathrm{yr}$." The soil is a moderately well-drained sandy clay loam belonging to Rhodudults. ${ }^{4}$ The $\mathrm{pH}, \mathrm{CEC}$ and $\mathrm{C}: \mathrm{N}$ ratio are $6.5,16 \mathrm{me} / 100 \mathrm{~g}$ and 10 respectively. Dominant minerals are quartz and kaolinite with $\mathrm{Ca}$ and $\mathrm{Mg}$ being the dominant cations. The sub-soil base saturation is $25 \%$. The respective soil water contents at field capacity and permanent wilting point are $26 \%$ and $12 \% . "$

Experimental treatments: The experimental treatment structure was a two-factor factorial with tree species and trenching as the two factors laid out in a split-plot design. There were six tree or perennial shrub species (Calliandra calothyrsus Meissn., Desmodium ransonii (L.) DC., Flemingia macrophylla (Willd.) Merr., Gliricidia sepium (Jacq.) Steud., Cassia spectabili.s (L.) DC. and Tithonia diversifolica. (Hems].) A. Gray in hedgerow intercrops with mung bean (Vigna radiala (L.) Wilczek) plus a sole crop of mung bean used as the control. Within each h(:dgerow intercrop (i.e. main plot factor), there were trenching (TR) and no-trenching (NTR) treatments as the sub-plot factor (Fig. 1). In the trenching treatment, a $1.5 \mathrm{~m}$ deep trench was cut at $25 \mathrm{~cm}$ from the hedgerow to prevent lateral growth of tree roots to the area planted with mung bean. This treatment structure was replicated three times.

Establishment of hedgerows and annual crops: The tree hedges were established in 1992 as double hedgerows ( $15 \mathrm{~cm}$ apart) along contours in a land with an even slope of $10 \%$. The distance between two adjacent double hedgerows was $4-5 \mathrm{~m}$. Mung bean (variety MI-5) was established in the alleys between hedgerows at an inter-row spacing of $30 \mathrm{~cm}$ and an intra-row spacing of $10 \mathrm{~cm}$. Each experimental sub-plot consisted of a hedgerow length of $5 \mathrm{~m}$ and its associated mung bean plot area spanning the whole width of the alley. 


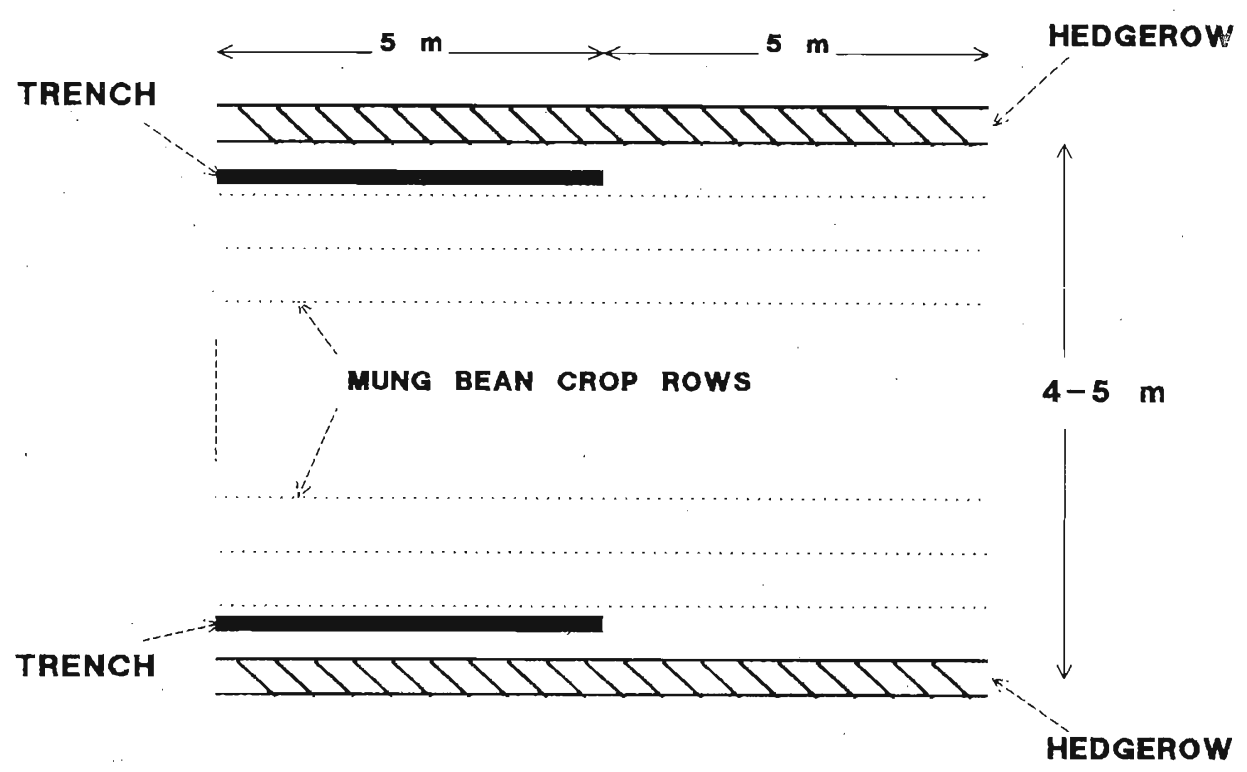

Figure 1: Schematic representation of a split -plot indicating the trenching (TR) and non-trenching (NTR) treatment. Mung bean crop rows were spaced at 30 $\mathrm{cm}$ apart with an intra-row spacing of $10 \mathrm{~cm}$. The trenches were at a distance of $25 \mathrm{~cm}$ from the hedgerows. See text for more details.

Mung bean was sown on 23 June 1998. All hedgerows were pruned to a height of $0.5 \mathrm{~m}$ on 20 June 1998 and the prunings were deposited between the double hedgerows. Thereafter, the hedges were allowed to grow freely during the cropping season. Mung bean crops were grown without any additions of chemical fertilizers or organic manure. Weeds were controlled manually and pests and diseases were controlled by periodic spraying of appropriate pesticides.

Measurements: Vegetative growth of mung bean was measured at 50\% flowering (i.e. 50 days after sowing). Measurements were done separately on samples of five randomly-selected plants from each row within the alley. Leaf area was measured by an automatic leaf area meter and total dry weight was measured after oven-drying at $80^{\circ} \mathrm{C}$ to a constant weight. Mung bean yield was obtained by harvesting the pods in three different picks at 70,80 and 90 days after sowing (DAS). Yields of all crop rows were measured separately by harvesting all plants in a pre-determined row length of $1 \mathrm{~m}$ from the central area of each plot. In addition to pod yield, yield components (i.e. number of pods per plant, number of seeds per pod and hundred-seed dry weight) were measured in each crop row. All corresponding growth and yield measurements were done on sole crop control plots also. 
The central $4 \mathrm{~m}$ length of hedgerow in each plot was pruned to a height of $0.5 \mathrm{~m}$ at final harvesting of mung bean. Fresh weight of pruned biomass was measured in the field immediately after pruning. A sub-sample of prunings of each plot was oven-dried at $80^{\circ} \mathrm{C}$ to a constant weight to obtain the dry weight of pruned biomass.

Data analysis: Leaf area index (L) of mung bean was calculated as total leaf area per unit land area. Total dry weight (W) of mung bean and dry biomass of hedgerows were expressed on a per ha basis. In the calculations of $\mathrm{L}$ and $\mathrm{W}$, adjustments were made to account for the land area occupied by hedgerows. Mung bean yield ( $\mathrm{Y}$ ) was expressed as pod dry weight per ha. Analysis of variance was used to test the significance of the effects of different tree species, trenching and their interaction. Whenever a given effect was significant at $p=0.05$ or below, standard error of mean was used to separate the means.

The magnitudes of shoot (above-ground) and root (below-ground) competitions were estimated on the basis of mung bean pod yields (Y) using the following equations:

$$
\begin{aligned}
& \text { Shoot competition }=\mathrm{YC}-\mathrm{YH}_{\mathrm{TR}} \\
& \text { Root competition }=\mathrm{YH}_{\mathrm{TT}}-\mathrm{YH}_{\mathrm{NTK}}
\end{aligned}
$$

where $\mathrm{YC}$ is sole mung bean yield; $\mathrm{YH}_{\mathrm{TR}}$ and $\mathrm{YH}_{\mathrm{NTR}}$ are respective mung bean yields in hedgerow intercrops with and without trenching. The above absolute estimates of competition were also expressed as percentages of total competition (i.e. $\mathrm{YC}-\mathrm{YH}_{\mathrm{NTR}}$.

Inter-relationships between pod yield and yield components were estimated by multiple correlation analysis. ${ }^{6}$

\section{RESULTS}

\section{Meteorological conditions during the experimental period:}

The total rainfall received during the experimental period (Table 1), i.e. $574.8 \mathrm{~mm}$, is lower than that received during the previous season, i.e. $1237 \mathrm{~mm} .^{2}$ However, the monthly rainfall exceeded pan evaporation in all months except August. Therefore, the crops did not experience any significant drought. Temperature and radiation levels did not show much variation during the experimental period.

\section{Leaf area index (L) and total biomass (W) of mung bean:}

The main effects of tree species and trenching on both $\mathrm{L}$ and $\mathrm{W}$ were highly significant $(\mathrm{p}<0.001)$. However, species $\mathrm{x}$ trenching interaction effects were not significant at $p=0.05$. Hedgerows of all tree species tested caused significant 
Table 1: Meteorological conditions during the experiment

\begin{tabular}{lccccc}
\hline & $\begin{array}{c}\text { Rainfall } \\
(\mathrm{mm})\end{array}$ & $\begin{array}{c}\text { Pan } \\
\text { Evaporation } \\
(\mathrm{mm})\end{array}$ & $\begin{array}{c}\text { Mean } \\
\text { Incident } \\
\text { Radiation } \\
\left(\mathrm{MJm}^{-2} \mathrm{~d}^{-1}\right)\end{array}$ & $\begin{array}{c}\text { Mean } \\
\text { Max. } \\
\text { Temp. } \\
\left({ }^{0} \mathrm{C}\right)\end{array}$ & $\begin{array}{c}\text { Mean } \\
\text { Min. }\end{array}$ \\
\hline June & $91.9(11)^{1}$ & 90.0 & 15.91 & 29.9 & 22.8 \\
July & $201.2(11)$ & 86.8 & 17.04 & 29.0 & 22.0 \\
August & $70.2(9)$ & 77.5 & 18.05 & 28.5 & 21.4 \\
September & $112.9(10)$ & 93.0 & 17.74 & 29.2 & 21.4 \\
October & $98.6(11)$ & 68.2 & 16.77 & 29.2 & 21.0 \\
\hline
\end{tabular}

${ }^{1}$ Number of days with a rainfall greater than $2 \mathrm{~mm}$

${ }^{2}$ Estimated from measured duration of sunshine

Table 2: Leaf area index (L) and total dry weight (W) of mung bean crops (at $50 \%$ flowering) growing under different hedgerow tree species with (TR) and without (NTR) trenching.

\begin{tabular}{|c|c|c|c|c|}
\hline \multirow{2}{*}{ Thee species } & \multicolumn{2}{|c|}{ Leaf area index } & \multicolumn{2}{|c|}{ Tot. dry wt. $\left(\mathrm{kg} \mathrm{ha}^{-1}\right)$} \\
\hline & $\mathrm{TR}$ & NTR & $\mathrm{TR}$ & NTR \\
\hline Control & \multicolumn{2}{|c|}{0.491} & \multicolumn{2}{|c|}{943.4} \\
\hline Cassia & 0.175 & 0.139 & 196.1 & 146.1 \\
\hline Calliandra & 0.394 & 0.204 & 434.3 & 196.2 \\
\hline Gliricidia. & 0.299 & 0.240 & 464.3 & 469.0 \\
\hline Flemingia & 0.177 & 0.109 & 210.9 & 127.6 \\
\hline Tithonia & 0.339 & 0.214 & 298.3 & 199.4 \\
\hline Desmodium & 0.299 & 0.254 & 272.7 & 270.0 \\
\hline Mean & 0.311 & 0.236 & 402.9 & 336.0 \\
\hline $\mathrm{SE}(\mathrm{df}=6)$ & \multicolumn{2}{|c|}{0.037} & \multicolumn{2}{|c|}{77.21} \\
\hline
\end{tabular}

Note: SE-Standard error for mean comparisons between tree species $\mathrm{x}$ trenching treatmenet combinations. 
growth reductions in mung bean in both trenching (TR) and non-trenching (NTR) treatments (Table 2). The reductions in $\mathrm{L}$ and $\mathrm{W}$ due to the presence of hedgerows were greatest in mung bean grown with Cassia and Flemingia. In NTR treatments, the highest growth was shown by mung bean grown with Gliricidia and Desmodium. With trenching, both $\mathrm{L}$ and $\mathrm{W}$ of mung bean increased under all hedgerow tree species with the highest increases being shown in mung bean with Calliandra and Tithonia (Table 2). On the other hand, the positive responses of $\mathrm{L}$ and $W$ to trenching were lower in mung bean crops with Gliricidia and Desmodium.

\section{Mung bean yield (Y) and estimates of competition:}

Mung bean yields varied significantly with the associated hedgerow tree species $(p<0.001)$ and trenching $(p<0.05)$ treatment. The effect of tree species $x$ trenching interaction on mung bean yield was not significant at $p=0.05$. Presence of hedgerows caused significant reductions in $Y$ in both TR and NTR treatments (Table 3). The highest and the lowest yield reductions were shown by mung bean crops with Cassia and Gliricidia respectively. Within each tree species, mung bean crops grown with trenching had greater $\mathrm{Y}$ as compared to those grown without trenching. The greatest positive response to trenching in terms of $\mathrm{Y}$ was shown in mung bean with Calliandra whereas mung bean with Cassia and Tithonia showed the lowest positive response (Table 3 ).

Table 3: Variation of mung bean yield under different bedgerow tree species and trenching treatments along with estimates of shoot and root competition

\begin{tabular}{|c|c|c|c|c|c|c|c|}
\hline \multirow[t]{2}{*}{$\begin{array}{l}\text { Tree } \\
\text { species }\end{array}$} & \multicolumn{2}{|c|}{$\begin{array}{c}\text { Pod dry wt. } \\
\left(\mathrm{kg} \mathrm{ha}^{-1}\right)\end{array}$} & \multicolumn{2}{|c|}{$\begin{array}{c}\text { Competition } \\
\text { (Absolute) } \\
\left(\mathrm{kg} \mathrm{ha}^{-1}\right) \\
\end{array}$} & \multicolumn{2}{|c|}{$\begin{array}{l}\text { Competition } \\
\text { (Percentage } \\
\text { of total) }(\%)\end{array}$} & \multirow[t]{2}{*}{$\begin{array}{c}\mathrm{Y}_{1} \\
(\mathrm{~kg} \\
\left.\mathrm{ha}^{-1}\right) \\
\end{array}$} \\
\hline & $\mathrm{TR}$ & NTR & Shoot & Root & Shoot & Root & \\
\hline Control & \multicolumn{2}{|c|}{806.3} & & & & & 491.5 \\
\hline Cassia & 142.5 & 105.3 & 663.8 & 37.2 & 94.7 & 5.3 & 196.6 \\
\hline Calliandra & 455.3 & 265.7 & 351.0 & 189.6 & 64.9 & 35.1 & 127.0 \\
\hline Gliricidia & 686.8 & 563.3 & 119.5 & 123.5 & 49.2 & 50.8 & 582.9 \\
\hline Flemingia & 310.6 & 202.1 & 495.7 & 108.5 & 82.0 & 18.0 & 247.4 \\
\hline Tithonia & 361.8 & 317.8 & 444.5 & 44.0 & 91.0 & 9.0 & 157.2 \\
\hline Desmodium & 330.2 & 201.0 & 476.1 & 129.2 & 78.7 & 21.3 & 943.3 \\
\hline Mean & 441.9 & 351.6 & & & & & \\
\hline $\mathrm{SE}(\mathrm{df}=6)$ & & & & & & & \\
\hline
\end{tabular}

Note: - See text for explanation. $Y_{\mathrm{p}}$ - Yield of previous season (based on De Costa and Cliandrapala, 2000). 
Table 3 also shows the estimates of shoot and root competition from different hedgerow tree species based on yield variation between TR and NTR treatments with sole crop yield as the control. The highest shoot competition, in both absolute and percentage terms, was shown by Cassia whereas Gliricidia showed the lowest shoot competition. In terms of absolute yield reduction, root competition was highest in mung bean with Calliandra and lowest with Cassia. On the other hand, when considered as a percentage of the total yield reduction relative to the control, the percentage root competition was highest in mung bean with Gliricidia (Table 3). When the total yield reduction due to the presence of hedgerows was partitioned as being due to shoot and root competition, only Gliricidia and Calliandra showed percentage root competition levels which exceeded $25 \%$. Shoot competition was the dominant component in all hedgerow species except Gliricidia where the two components were approximately equal. The last column of Table 3 shows the corresponding pod yields obtained in the previous season ${ }^{2}$ in which trenching was not practised. Despite the lower rainfall, the sole mung bean yield has nearly doubled in the present season. Yields of some hedgerow intercrops (NTR treatments) have increased (e.g. with Calliandra and Tithonia) whereas the others have decreased. The most drastic yield reduction has occurred in mung bean with Desmodium which had the highest yield in the previous season.

\section{Mung bean yield components:}

Variation of the number of pods per plant (NP), number of seeds per pod (SP) and hundred seed weight (SW) in mung bean crops under different hedgerow tree species and trenching treatments are shown in Table 4. There were highly significant $(p<0.0001)$ differences between tree species in all yield components. With the exceptions of SP under Gliricidia and Desmodium and SW under Desmodium, yield components of mung bean with different tree species responded positively to trenching. In the NTR treatment, presence of hedgerows decreased NP significantly $(p<0.05)$ in all mung bean crops except those with Gliricidia. The greatest reduction of NP was in mung bean with Cassia. Although trenching increased NP in mung bean crops with all tree species, the comparative ranking of different tree species in the TR treatment was similar to that of NTR. In NTR treatments, SP of mung bean decreased significantly $(\mathrm{p}<0.05)$ due to the presence of all tree species with the reductions being lowest under Calliandra and Gliricidia and highest under Cassia and Tithonia. In TR treatments, the lowest reductions in SP were shown under Flemingia and Calliandra and highest reductions were under Cassia and Tithonia. Inter-treatment variation of SW showed a slight difference from the corresponding variations of NP and SP. In NTR treatments, only the mung bean crops under Tithonia, Cassia and Flemingia showed significant $(p<0.05)$ reductions in SW. On the other hand, in TR treatments, mung bean with Calliandra and Flemingia had significantly. $(\mathrm{p}<0.05)$ greater $\mathrm{SW}$ than the sole crop control. In contrast, the opposite was shown under Tithonia, Cassia and Desmodium (Table 4). 
Table 4: Variation of mung bean yield components under different hedgerow tree species and trenching treatments

\begin{tabular}{|c|c|c|c|c|c|c|}
\hline \multirow{2}{*}{$\begin{array}{l}\text { Tree } \\
\text { species }\end{array}$} & \multicolumn{2}{|c|}{ Pods per plant } & \multicolumn{2}{|c|}{ Seeds per pod } & \multicolumn{2}{|c|}{ 100-seed wt. (g) } \\
\hline & TR & NTR & TR & NTR & $\mathrm{TR}$ & NTR \\
\hline Control & \multicolumn{2}{|c|}{4.74} & \multicolumn{2}{|c|}{8.18} & \multicolumn{2}{|c|}{5.49} \\
\hline Cassia & 1.35 & 0.94 & 4.90 & 4.60 & 5.02 & 5.49 \\
\hline Calliandra & 3.63 & 2.17 & 7.29 & 6.76 & 5.99 & 4.82 \\
\hline Gliricidia & 5.51 & 4.39 & 6.06 & 6.75 & 5.64 & 5.44 \\
\hline Flemingia & 2.87 & 1.71 & 7.44 & 5.36 & 5.92 & 5.34 \\
\hline Tithonia & 1.41 & 1.20 & 4.49 & 4.22 & 4.22 & 5.02 \\
\hline Desmodium & 2.47 & 1.58 & 5.64 & 5.92 & 5.08 & 4.09 \\
\hline Mean & 3.14 & 2.39 & 6.28 & 5.97 & 5.34 & 5.07 \\
\hline $\begin{array}{l}S E \\
(d f=72)\end{array}$ & \multicolumn{2}{|c|}{0.248} & \multicolumn{2}{|c|}{0.222} & \multicolumn{2}{|c|}{0.135} \\
\hline
\end{tabular}

Correlations between yield and yield components:

In both TR and NTR treatments, mung bean seed yields showed highly significant $(\mathrm{p}<0.0001)$ positive correlations with all yield components (Table 5). The strongest correlation was with the number of pods per plant with $\mathrm{r}^{2}$ exceeding 0.9 . Moreover, all yield components showed highly significant positive correlations among themselves.

Table 5: Linear correlation coefficients between pod yield and yield components of mung bean crops grown under different hedgerow tree species with trenching (above the diagonal) and without trenching (below the diagonal)

\begin{tabular}{lcccc}
\hline & $\begin{array}{c}\text { Pod dry wt. } \\
\text { per plant }\end{array}$ & Pods per plant & $\begin{array}{c}\text { Seeds per } \\
\text { pod }\end{array}$ & $\begin{array}{c}\text { 100-seed } \\
\text { weight }\end{array}$ \\
\hline Pod dry wt. per plant & - & 0.910 & 0.516 & 0.417 \\
Pods per plant & 0.915 & - & 0.541 & 0.455 \\
Seed per pod & 0.586 & 0.636 & - & 0.685 \\
100 -seed weight & 0.400 & 0.400 & 0.671 & - \\
\hline
\end{tabular}

Note: All correlation coefficients were significant at $p<0.001$ 


\section{Biomass production of hedgerow tree species:}

There were highly significant $(\mathrm{p}<0.001)$ differences between tree species in their above-ground biomass production during the 90-day duration of the mung bean crop. In both TR and NTR treatments, Cassia and Flemingia had the highest and lowest biomass production levels respectively (Table 6). Tithonia, Gliricidia and Calliandra also showed higher levels of biomass which were significantly $(\mathrm{p}<0.05)$ greater than those of Flemingia and Desmodium, but significantly lower than that, of Cassia. There was a slight decrease in above-ground biomass production due to trenching in all tree species (Table 6). Despite the lower rainfall, biomass production of all tree species in the present season (in NTR treatments) was higher than in the previous season.

Table 6: Biomass production of different hedgerow tree species with (TR) and without (NTR) trenching

\begin{tabular}{lccc}
\hline Tree species & \multicolumn{3}{c}{ Biomass produced $\left(\mathrm{x} 10^{3} \mathrm{~kg} \mathrm{ha}^{-1}\right)$} \\
\cline { 2 - 4 } Cassia & TR & NTR & Wp \\
Calliandra & 5.88 & 6.11 & 3.48 \\
Gliricidia & 4.63 & 4.72 & 1.44 \\
Flemingia & 4.63 & 4.72 & 2.21 \\
Tithonia & 0.42 & 0.56 & 0.33 \\
Desmodium & 4.77 & 5.00 & 2.32 \\
\hline Mean & 1.20 & 1.30 & 0.98 \\
Se (df=6) & 3.59 & 3.74 & 1.79 \\
\hline
\end{tabular}

Note: Wp-Biomass production of previous season ${ }^{2}$

\section{DISCUSSION}

The main finding of this experiment was the dominance of above-ground (shoot) competition over below-ground (root) competition in the present environment. This contrasted with the findings of Singh et $a l .{ }^{7}$, Rao et $a l .{ }^{8}$, Rao et al. ${ }^{9}$ and Ong et $a l .{ }^{10}$ who observed significant below-ground competition. However, dominance of below-ground competition could vary with the availability of below-ground resources such as soil nutrients ${ }^{11}$ and moisture. ${ }^{12,13}$ These aspects of the present experiment will be reported in De Costa and Chandrapala. ${ }^{14}$

It is also possible that root systems of hedgerow species and mung bean may have occupied complementary zones in the soil profile which would have minimized 
the competition for absorption of water and nutrients. Such a situation has been observed by Huxley et al..$^{15}$ in a Grevillea robusta x maize hedgerow intercropping system. Observed variation in below-ground competition between tree species could be because of the variation in the extent and depth of their root systems. ${ }^{16,17}$ Teubig (unpublished) who studied the morphology of hedgerow root systems in the present site observed that Gliricidia had a shallow and spreading root system whereas the other tree species had deeper and less-spreading root systems. This may explain the greater percentage below-ground competition by Gliricidia. Experiments will be carried out in the next phase of this programme to provide detailed, quantitative information on the root systems of hedgerows and the annual crop at the present site.

The significant inter-species variation in above- and below-ground competition observed in the present experiment could indicate possible variation in the balance between negative competition effects and positive 'fertility' effects $^{18,1: "}$ of different tree species on associated mung bean. The significant variation in biomass production between the different tree species could determine the magnitude of overall competition exerted. ${ }^{16,20}$ For example, the highest overall competition effect was shown in mung bean grown with Cassia which had the highest biomass production. The demand for both above- and below-ground resources is likely to be greater with higher biomass production, thus intensifying competition on the annual crop. However, among the other tree species, similar magnitudes of overall competition have been observed in mung bean crops grown with tree species which had large differences in biomass production such as Tithonia and Flemingia. This could be due to the differences in the fertility effect of the above two species. Firstly, the large amount of prunings added to mung bean crops grown with Tithonia (which had a higher biomass production) would have added a greater amount of nutrients on decomposition. In contrast, the fertility effect of mung bean associated with Flemingia (which had a lower biomass production) would be comparatively low. Secondly, De Costa and Atapattu ${ }^{21}$ observed in a separate study that the rate of decomposition of Tithonia mulch is much faster than that of Flemingia. Hence, both the amount of prunings added as mulch and the degree of synchrony of nutrient release with the nutrient demand of the annual crop ${ }^{22,23}$ can determine the fertility effect of a given hedgerow species on the annual crop.

A secondary objective of this experiment was to compare the degree of competition exerted by different hedgerow species in the present experiment with that observed in the previous season as reported in De Costa and Chandrapala. ${ }^{2}$ Comparison of the estimates of overall tree-crop interaction showed some notable differences between the two seasons such as Desmodium changing from a substantially positive to negative interaction. However, in terms of absolute mung bean yield, except for the crops with Desmodium, the comparative ranking of hedgerow species did not differ much between the two seasons. 
The magnitude of tree-crop competition and the level of annual crop (i.e. mung bean) yield could change from season to season because of several factors. These include variation in growth of different tree species, the level of resources (e.g. nutrients) removed for tree and crop growth in the previous season and the level of resources added to the system (e.g. tree prunings and crop residues) from the previous season. ${ }^{24,25}$ For example, plots with Desmodium had an extremely high mung bean yield in the previous season and removed a high amount of nitrogen ${ }^{26}$ while providing only a small amount of prunings from Desmodium. This could be the reason for the substantial decrease of mung bean yield in plots with Desmodium in the present season. Therefore, long-term observations of crop yields are needed to ascertain the sustainability of a hedgerow intercropping system involving a specific tree species.

The dominance of above-ground competition observed in the present experiment means that appropriate hedgerow management practices should. be formulated to minimize shoot competition. These could include pruning of hedgerows in the middle of the cropping season instead of waiting until the harvesting of mung bean.

\section{Acknowledgement}

This research was funded by the International Foundation for Science, Sweden with the advice of Dr. C.K. Ong (ICRAF, Nairobi, Kenya). Assistance of K. B. Attanayake (Department of Crop Science) and Dr. M. Herath and his staff of the Environment and Forestry Division of the Mahaweli Authority is gratefully acknowledged.

\section{References}

1. Sanchez P.A. (1995). Science in agroforestry. Agroforestry Systems 30 : 5-55.

2. De Costa W.A.J.M. \& Chandrapala A.G. (2000a). Effects of different tree species on growth and yield of mung bean (Vigna radiata (L.) Wilczek) grown in hedgerow intercropping systems in Sri Lanka. Journal of Agronomy and Crop Science 184: 43-48.

3. Panabokke C.R. (1996). Soils and agro-ecological environments of Sri Lanka. Natural Resources, Energy and Science Authority of Sri Lanka.

4. Moormann F.R. \& Panabokke C.R. (1961). Soils of Ceylon. Tropical Agriculturist 117: 1-69.

5. Mapa R.B. \& Pathmarajah P. (1995). Contrasts in the physical properties of three soils of an Alfisol catena in Sri Lanka. Soil Use and Management 11: 90-93. 
6. Little T.M. \& Hills F.J. (1978). Agricultural experimentation: design and analysis. John Wiley \& Sons, New York.

7. Singh R.P., Ong C.K. \& Saharan N. (1989). Above and below ground competitions in alley cropping in semi-arid India. Agroforestry Systems 8: 259-274.

8. Rao M.R., Sharma M.M. \& Ong C.K. (1990). A study of the potential of hedgerow intercropping in semi-arid India using a two-way systematic design. Agroforestry Systems 11: 243-258.

9. Rao M.R., Ong C.K., Pathak P. \& Sharma M.M. (1991). Productivity of annual cropping agroforestry systems on a shallow Alfisol in semi-arid India. Agroforestry Systems 15: 51-63.

10. Ong C.K., Corlett J.E., Singh R.P. \& Black C.R. (1991). Above and below ground interactions in agroforestry systems. Forest Ecology and Management 45: 45-57.

11. Fernandes E.C.M., Davey, C.B. \& Nelson, L.A. (1993). Alley cropping on an acid soil in the upper Amazon: mulch, fertilizer and hedgerow root pruning effects. In: Technologies for sustainable agriculture in the tropics (Eds. J. Ragland \& R. Lal) pp. 77-96. ASA Special publication 56, American Society of Agronomy, Madison, WI 53711, USA.

12. Govindarajan M., Rao M.R., Mathuva M.N. \& Nair P.K.R. (1996). Soil-water and root dynamics under hedgerow intercropping in semiarid Kenya. Agronomy Journal 88: 513-520.

13. McIntyre B.D., Riha S.J. \& Ong C.K. (1997). Competition for water in a hedge-intercrop system. Field Crops Research 52: 151-160.

14. De Costa W.A.J.M. \& Chandrapala A.G. (2000b). Effects of tree root competition on availability of soil and plant nutrients, soil water and light interception in hedgerow intercrops with different tree species in Sri Lanka. Journal of the National Science Foundation of Sri Lanka 28 (2): 127-142.

15. Huxley P.A., Pinney A., Akunda E. \& Muraya P. (1994). A tree/crop interface orientation experiment with a Grevillea robusta hedgerow and maize. Agroforestry Systems 26: 23-45.

16. Ruhigwa B.A., Gichuru M.P., Mambani B. \& Tariah N.M. (1992). Root distribution of Acioa barteri, Alchornea cordifolia, Cassia siamea and Gnuelina arborea in an acid Ultisol. Agroforestry Systems 19: 67-78. 
17. van Noordwijk M. \& Purnomosidhi P. (1995). Root architecture in relation to tree-soil-crop interactions and shoot pruning in agroforestry. Agroforestry Systems 30: 161-173.

18. Ong C.K. (1996). A framework for quantifying the various effects of tree-crop interactions. In: Tree-crop interactions: a physiological approach (Eds. C.K. Ong \& P. Huxley) pp. 1-23. CAB International, UK.

19. Cannell M.G.R., van Noordwijk M. \& Ong C.K. (1996). The"central agroforestry hypothesis: the trees must acquire resources that the crop would not otherwise acquire. Agroforestry Systems 34: 27-31.

20. Huxley P.A. (1996). Biological factors affecting form and function in woody-non-woody plant mixtures. In: Tree-crop interactions: a physiological approach (Eds. C.K. Ong \& P. Huxley) pp. 235-298. CAB International, UK.

21. Myers R.J.K., Palm C.A., Cuevas E., Gunatilleke I.U.N. \& Brossard M. (1994). The synchronization of nutrient mineralisation and plant nutrient demand. In: The biological management of tropical soil fertility (Eds. P.L. Woolmer \& M.J. Swift). John Wiley \& Sons, Chichester, UK.

22. De Costa W.A.J.M. \& Atapattu A.M.L.K. (2000). Decomposition and nutrient loss from prunings of different contour hedgerow species in tea plantations in the sloping highlands of Sri Lanka. Agroforestry Systems (In Press).

23. Mafongoya P.L., Giller K.E. \& Palm C.A. (1998). Decomposition and nitrogen release patterns of tree prunings and litter. Agroforestry Systems 38: 77-97.

24. van Noordwijk M., Sitompul S.M., Hairiah K., Listyarini E. \& Syekhfani M.S. (1995). Nitrogen supply from rotational or spatially zoned inclusion of Leguminosae for sustainable maize production on an acid soil in Indonesia. In: Plant-soil interactions at low pH (Eds. R.A. Date, N.J. Grundon, G.E. Rayment \& M.E. Probert) pp. 779-784. Kluwer, Dordrecht, The Netherlands.

25. Rao M.R., Nair P.K.R. \& Ong C.K. (1998). Biophysical interactions in tropical agroforestry systems. Agroforestry Systems 38: 3-50.

26. De Costa W.A.J.M. \& Chandrapala A.G. (2000c). Environmental interactions between different tree species and mung bean (Vigna radiata (L.) Wilczek) in hedgerow intercropping systems in Sri Lanka. Journal of Agronomy and Crop Science 184: 145-152 